\title{
Application of correlation and regression analysis in the selection of black-and-white cows
}

\author{
I.M. Donnik, and O.S. Chechenikhina* \\ Ural State Agrarian University, Yekaterinburg, Russia
}

\begin{abstract}
The use of the method of correlation-regression analysis as the most widespread method of statistical processing of experimental data makes it possible to organize the selection of animals according to the leading characteristics of productivity. A positive and high correlation was established between milk yield and milk yield in all groups of studied animals ( $\mathrm{r}=$ from 0.64 to 0.90$)$, and between milk yield in 305 days of lactation and the highest daily milk yield - only in groups of Reflection Sovering and Montvik Chieftain cows. $(r=0.65$ to 0.92$)$. Cows of the Vis Back Aydial line have higher correlation coefficients between indicators of milk composition ( $\mathrm{r}=$ from 0.72 to 0.91 , depending on the trait). The calculation of the regression coefficients showed that in the studied groups of animals with an increase in the coefficient of constancy of lactation, the coefficient of milk production and the indicator of the highest daily milk yield per unit, the amount of milk for 305 days of lactation increased by an average of $1.63-221.04 \mathrm{~kg}$.
\end{abstract}

\section{Introduction}

Breeding work with the black-and-white breed of cattle has been carried out by specialists in our country for almost thirty years and is aimed at increasing the genetic resources of milk production of cows. Evaluation and selection of cows from among the descendants of bulls of various lines in this direction of work is given a special place. Line breeding is currently one of the main methods of improving black-and-white cattle. The genealogical structure of the black-and-white cattle of the Ural type is mainly characterized by the Vis Back Aydial, Reflection Sovering, Montvik Chieftain and Sealing Trijun Rokit lines [1, $2]$.

Efficient milk production under different ecological and forage conditions for breeding blackand-white cows should be combined taking into account the indicators characterizing milk productivity, adaptive plasticity and individual qualities of animals $[3,4,5,6,7,8,9]$.

The biological and productive characteristics of black-and-white Ural type cows are in constant transformation through selection work. That is why the identification of interrelationships between

\footnotetext{
* Corresponding author: olgachech@yandex.ru
} 
the traits characterizing the productive qualities of animals is the main direction of the activities of specialists and researchers working to improve the efficiency of cow breeding [10, 11, 12, 13, 14].

The method of correlation-regression analysis is one of the most widespread methods of statistical processing of experimental data. This method has been used since 1795, when the English researcher Francis Galton proposed to introduce the term "correlation" into statistics. At the same time, for the first time the correlation-regression analysis was applied in practice by the French scientist Georges Cuvier.

The use of correlation-regression analysis in the breeding of dairy cattle made it possible to successfully predict the level of milk productivity of animals in many herds, as evidenced by various studies in this direction $[15,16,17,18,19,20]$.

The study of the correlation between breeding traits makes it possible in the process of cattle selection to focus on the leading traits - milk yield, quality indicators and basic properties of milk. Regression analysis, in turn, makes it possible to improve cow selection systems to increase the efficiency of selection and breeding work in the herd.

The aim of the research was to study the results of correlation-regression analysis in the selection of Ural-type black-and-white cows.

\section{Materials and methods}

The research was carried out on the basis of breeding enterprises of the Sverdlovsk region, specializing in breeding cattle of the Ural type of black-and-white breed.

The work used notes of cows' individual cards, milk logs, data from the SELEX information management system for the period from 2013 to 2019. The interconnections between the productive qualities of cows from among the descendants of bulls of Holstein lines were analyzed: Vis Back Aydial $1013415(\mathrm{n}=1401)$, Reflection Sovering $198998(\mathrm{n}=$ 816), Montvik Chieftain $95679(\mathrm{n}=360)$ and Sealing Trijun Rockit $252803(\mathrm{n}=738) \ldots$

The assessment of breeding and productive qualities of the studied animals was made in accordance with the "Procedure and conditions for assessing pedigree cattle of dairy and dairy-meat productivity", with "Rules for keeping records in pedigree cattle breeding of dairy and milk-meat productivity", with GOST R 57878-2017 Breeding farm animals. Methods for determining the productivity parameters of dairy and combined cattle. The processing of the obtained results was carried out using the Microsoft Excel program when calculating the main statistical values. The coefficients of correlation and regression between the studied traits of animals of different lines were calculated. The assessment of the statistical significance of the data obtained was carried out according to the Student's ttest (correlation coefficient r) and Fisher's F-test (regression coefficient R) [21].

\section{Research results}

A high dependence has been established between the indicators of milk productivity of cows. In the studied groups of animals of different lines, a positive correlation was observed between milk yield in 305 days of lactation and the coefficient of constancy of lactation $(\mathrm{r}=$ from 0.37 to $0.58(\mathrm{p}<0.05))$, the highest daily milk yield ( $\mathrm{r}=$ from 0.23 up to $0.92(\mathrm{p}<0.001))($ table 1$)$.

The interrelation between milk yield and milk yield is high and positive $(r=0.64$ to $0.90(p<0.001))$. Our data are confirmed by the results obtained in the studies of T.I. Berezina [22], where the correlation between the above features is also high and positive ( $\mathrm{r}$ $=$ from 0.63 to 0.96 ). In animals of various lines, with an increase in the coefficient of constancy of lactation, the coefficient of milk production and the highest daily milk yield 
per unit, the milk yield per 305 days of lactation increased by an average of $1.63-221.04$ $\mathrm{kg}$.

Table 1. Correlation-regression analysis of milk productivity indicators of cows of the Ural type of black-and-white breed of various lines.

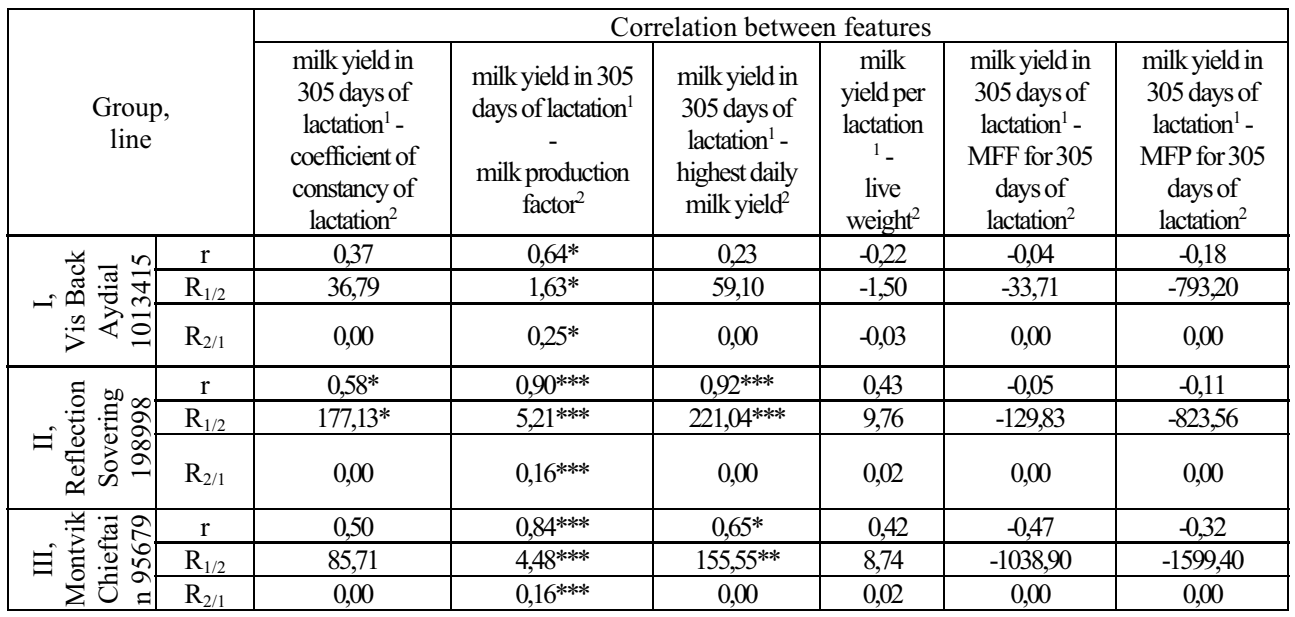

Note: hereinafter

MFF - mass fraction of fat in milk, MFP - mass fraction of protein in milk;

$*_{-} \mathrm{p}<0,05 ; * *-\mathrm{p}<0,01 ; * * *-\mathrm{p}<0,001$;

$1,2-$ index of the studied feature in a pair.

Scientific research of A.S. Batargalieva [16] proved that there is a low but positive correlation between the amount of milk received and its fat content $(r=$ from 0.220 to 0.222). In our work, milk yield and fat-milk, milk-protein of cows negatively correlated with each other (for fat $r=$ from -0.04 to -0.47 ; for protein $r=$ from -0.32 to -0.47 ). The regression coefficients showed that one percent increase in the proportion of fat and protein in milk resulted in a decrease in milk yield by 33.7 - $1599.4 \mathrm{~kg}$. T.A. Guseva [23-25] confirm our results.

In the work of A.V. Klipova [18], it was found that the cows under study had a positive, but not high, conjunction between milk yield and live weight $(\mathrm{r}=0.35)$. Our studies confirm this $(\mathrm{r}$ $=0.42-0.43$ ), except for the group of cows of the Vis Back Aydial line, where the conjunction between milk yield and live weight is negative $(r=-0.22)$.

In addition, we have established a negative relationship (or lack thereof) between the milk yield of cows of various lines (table 2) and indicators characterizing the composition of milk.

Table 2. Correlation-regression analysis of milk yield and indicators of the composition and properties of milk of Ural type cows of the black-and-white breed of various lines.

\begin{tabular}{|c|c|c|c|c|c|c|c|c|c|}
\hline \multirow{3}{*}{$\begin{array}{l}\text { Correlation } \\
\text { between } \\
\text { milk yield }^{1} \text { and }\end{array}$} & \multicolumn{9}{|c|}{ Group, line } \\
\hline & \multicolumn{3}{|c|}{$\begin{array}{c}\text { I, } \\
\text { Vis Back IDial } 1013415\end{array}$} & \multicolumn{3}{|c|}{$\begin{array}{c}\text { II, } \\
\text { Reflection Sovering } 198998\end{array}$} & \multicolumn{3}{|c|}{$\begin{array}{c}\text { III, } \\
\text { Montvik Chieftain } 95679\end{array}$} \\
\hline & $\mathrm{r}$ & $\mathrm{R}_{1 / 2}$ & $\mathrm{R}_{2 / 1}$ & $\mathrm{r}$ & $\mathrm{R}_{1 / 2}$ & $\mathrm{R}_{2 / 1}$ & $\mathrm{r}$ & $\mathrm{R}_{1 / 2}$ & $\mathrm{R}_{2 / 1}$ \\
\hline $\begin{array}{l}\text { Mass fraction of } \\
\text { SNF in milk }\end{array}$ & $-0,07$ & $-146,19$ & 0,00 & 0,00 & 2,10 & 0,00 & $-0,39$ & $-2849,70$ & 0,00 \\
\hline Density of milk ${ }^{2}$ & $-0,21$ & $-146,05$ & 0,00 & $-0,13$ & $-256,85$ & 0,00 & $-0,32$ & $-302,90$ & 0,00 \\
\hline $\begin{array}{l}\text { Mass fraction of } \\
\text { casein }^{2}\end{array}$ & $-0,10$ & $-525,12$ & 0,00 & $-0,10$ & $\begin{array}{c}- \\
2210,91\end{array}$ & 0,00 & $-0,36$ & $-2106,23$ & 0,00 \\
\hline Mass fraction of & $-0,19$ & $-2107,56$ & 0,00 & $-0,09$ & $-740,96$ & 0,00 & 0,00 & $-4,07$ & 0,00 \\
\hline
\end{tabular}




\begin{tabular}{|l|c|c|c|c|c|c|c|c|c|}
\hline whey proteins $^{2}$ & & & & & & & & & \\
\hline $\begin{array}{l}\text { Mass fraction of } \\
\text { dry matter }\end{array}$ & $-0,13$ & $-68,12$ & 0,00 & $-0,09$ & $-209,80$ & 0,00 & $-0,60^{*}$ & $-994,31^{*}$ & 0,00 \\
\hline $\begin{array}{l}\text { Mass fraction of } \\
\text { lactose }^{2}\end{array}$ & $-0,05$ & $-206,06$ & 0,00 & 0,02 & 398,90 & 0,00 & $-0,39$ & $-5490,94$ & 0,00 \\
\hline $\begin{array}{l}\text { Mass fraction of } \\
\text { ash }^{2}\end{array}$ & $-0,12$ & $-2979,53$ & 0,00 & $-0,08$ & $\begin{array}{c}- \\
10865,73\end{array}$ & 0,00 & $-0,31$ & $-33637,61$ & 0,00 \\
\hline
\end{tabular}

Thus, the milk yield of cows negatively correlated with the mass fraction of SNF in milk ( $\mathrm{r}=$ from 0.00 to -0.39$)$, the fraction of casein $(\mathrm{r}=$ from -0.10 to -0.36$)$, whey proteins $(\mathrm{r}=$ from 0,00 to -0.19$)$, dry matter $(\mathrm{r}=-0.09$ to $-0.60(\mathrm{p}<0.05))$, lactose $(\mathrm{r}=0.02$ to 0.39 ), ash ( $\mathrm{r}=-0.08$ to -0.31 ). Milk density is also negatively correlated with milk yield ( $\mathrm{r}$ $=-0.21$ to -0.32 ). At the same time, judging by the regression coefficients, with a change in the milk yield of cows of various lines per $1 \mathrm{~kg}$, the indicators of the composition and properties of milk did not change.

According to O.G. Loretts et al. [24], there are high and medium correlations between many indicators of the composition and properties of milk, which makes it possible to increase the values of the biochemical indicators of milk by conducting selection work on one or two characteristics.

In our studies, a mutual positive dependence of the indicators of the composition of milk among themselves in groups of cows of different lines was established (table 3).

Table 3. Correlation-regression analysis of indicators of the composition and properties of milk of Ural type cows of the black-and-white breed of various lines.

\begin{tabular}{|c|c|c|c|c|c|c|c|}
\hline & & & & Correlation betv & en features & & \\
\hline $\begin{array}{c}\text { Group, } \\
\text { line }\end{array}$ & & $\begin{array}{c}\text { mass } \\
\text { fraction of } \\
\text { SNF in } \\
\text { milk }^{1} \text { and } \\
\text { mass } \\
\text { fraction of } \\
\text { dry matter }\end{array}$ & $\begin{array}{l}\text { mass } \\
\text { fraction of } \\
\text { SNF in } \\
\text { milk }^{1} \text { and } \\
\text { mass } \\
\text { fraction of } \\
\text { fat }^{2}\end{array}$ & $\begin{array}{l}\text { mass fraction } \\
\text { of casein } \\
\text { and } \\
\text { mass fraction } \\
\text { of whey } \\
\text { proteins }^{2}\end{array}$ & $\begin{array}{l}\text { mass } \\
\text { fraction of } \\
\text { casein }^{1} \\
\text { and } \\
\text { bulk } \\
\text { protein }^{2}\end{array}$ & $\begin{array}{c}\text { mass } \\
\text { fraction of } \\
\text { dry matter } \\
\text { and } \\
\text { density of } \\
\text { milk }^{2}\end{array}$ & $\begin{array}{c}\text { mass } \\
\text { fraction of } \\
\text { dry matter }{ }^{1} \\
\text { and } \\
\text { mass } \\
\text { fraction of } \\
\text { lactose }^{2}\end{array}$ \\
\hline 递 $\approx$ & $\mathrm{r}$ & $0,74 * *$ & $0,72 * *$ & 0,05 & $0,91 * * *$ & $0,74 * *$ & $0,72 * *$ \\
\hline 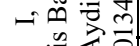 & $\mathrm{R}_{1 / 2}$ & $0,19 * *$ & $0,27 * *$ & 0,11 & $0,77 * * *$ & $0,19 * *$ & $0,27 * *$ \\
\hline$><0$ & $\mathrm{R}_{2 / 1}$ & $2,91 * *$ & $1,89 * *$ & 0,02 & $1,07 * * *$ & $2,91 * *$ & $1,89 * *$ \\
\hline .000 & $\mathrm{r}$ & 0,47 & 0,33 & 0,02 & 0,34 & 0,47 & 0,33 \\
\hline$\exists=$ & $\mathrm{R}_{1 / 2}$ & 0,1 & 0,08 & 0,01 & 0,1 & 0,1 & 0,08 \\
\hline$\approx$ in & $\mathrm{R}_{2 / 1}$ & 2,28 & 1,32 & 0,05 & 1,1 & 2,28 & 1,32 \\
\hline$\because \Xi a$ & $\mathrm{r}$ & 0,52 & 0,37 & 0,07 & $0,89 * * *$ & 0,52 & 0,37 \\
\hline$\Xi \underset{0}{0} 6$ & $\mathrm{R}_{1 / 2}$ & 0,11 & 0,1 & 0,13 & $0,72 * * *$ & 0,11 & 0,1 \\
\hline$\Sigma$ ¿ீ & $\mathrm{R}_{2 / 1}$ & 2,42 & 1,28 & 0,04 & $1,09 * * *$ & 2,42 & 1,28 \\
\hline
\end{tabular}

Thus, the mass fraction of SNF in cow milk turned out to be associated with a positive and high relationship with the fraction of dry matter $(\mathrm{r}=$ from 0.47 to $0.74(\mathrm{p}<0.01))$ and fat in milk $(\mathrm{r}$ $=$ from 0.33 to $0,72(\mathrm{p}<0.01))$. An increase in the share of SNF in milk by one percent brought up to $2.91 \%$ increase in dry matter and up to $1.89 \%$ fat.

Highly significant and positive correlation coefficients were found between the proportion of casein in milk and the proportion of total protein $(r=0.34$ to $0.91(p<0.001))$. An increase in the proportion of total protein led to an increase in the proportion of casein by $0.10-0.77 \%(p<0.001)$. Density of milk and mass fraction of lactose depend on the proportion of dry matter in milk. The correlation coefficients are equal, respectively, in terms of $r=$ from 0.17 to $0.82(p<0.01)$ and $r=$ from 0.48 to $0.74(p<0.01)$. For each 
percentage increase in the proportion of dry matter in milk accounted for up to $0.82{ }^{\circ} \mathrm{An}$ increase in milk density and up to $5.11 \%$ - in the proportion of lactose.

\section{Conclusions}

1. The correlation between milk yield and milk coefficient in all groups of studied animals was positive, significant and high $(\mathrm{r}=$ from 0.64 to 0.90$)$. Whereas the relationship between milk yield in 305 days of lactation and the highest daily milk yield is positive, reliable and high only in the groups of Reflection Sovering and Montvik Chieftain cows $(r=0.65$ to 0.92$)$. Negative correlations between milk yield and indicators of milk composition were found in all groups of the studied animals, but a significant relationship was found only in the group of the Montvik Chieftain line (the $r$ indicator between milk yield and dry matter mass fraction in milk is -0.60). At the same time, in the group of cows of the Vis Back Aydial line, there are higher and more reliable indicators of correlation between the traits that characterize the composition of milk $(\mathrm{r}=$ from 0.72 to 0.91 , depending on the feature).

2. Regression analysis showed that in groups of cows of different lines, with an increase in the coefficient of constancy of lactation, the coefficient of milk production and the indicator of the highest daily milk yield per unit, milk yield for 305 days of lactation increased by an average of $1.63-221.04 \mathrm{~kg}$. When the milk yield of cows changed per $1 \mathrm{~kg}$, the characteristics of the composition and properties of milk remained constant. One percent of the increase in the mass fraction of dry matter in milk in groups of cows of different lines was due to an increase in the density of milk to $0.82^{\circ} \mathrm{A}$ and the mass fraction of lactose to $5.11 \%$.

3. The established correlations between the studied features make it possible to select cows along the lines, aimed at increasing the indicators of the milk productivity of the herd. Regression analysis in these studies makes it possible to model the selection systems of cows in specific breeding herds to increase the efficiency of selection and breeding work. Knowing the quantitative variations of the measured characteristics of cows of different lines, taking into account the correlation analysis, specialists of the breeding service of enterprises have the opportunity to plan the results of their work within the framework of the selection of animals and the formation of a captive nucleus.

\section{References}

1. V.S. Mymrin, The focus is on breeding bulls, 1(149), 21 (2019)

2. V.F. Gridin, S.L. Gridina, O. I. Leshonok [and others], The results of selection and breeding work with black-and-white cattle of the Ural region for 2019, 92 (Yekaterinburg, Publishing house "G Lime" LLC, 2020)

3. E.S. Kazantseva, O.S. Chechenikhina, Glavny Zootechnik, 8, 19-23 (2015)

4. E.S.Kazantseva, O.S. Chechenikhina, Productive longevity of cows depending on the age of the first fruitful insemination, From inertia to development: scientific and innovative support for the development of animal husbandry and biotechnology: collection of articles. mater. international scientific-practical. conf., Ekaterinburg, 8384 (2020)

5. A.V. Stepanov [et al.], Proceedings of the Kuban State Agrarian University, 79, 207213 (2019) 
6. I.A. Bursa, O.V. Takhumova, D.I. Ryakhovsky, A.N. Ryakhovskaya, E.A. Batisheva, Research journal of pharmaceutical, biological and chemical sciences, 10, 1019-2024 (2019)

7. O.V. Gorelik, O.G. Loretts, O.P. Neverova, N.A. Fedoseeva, Influence of the age of the first insemination on the milk productivity of cows, Engineering support in the implementation of socio-economic and environmental programs of the agro-industrial complex: collection of articles. mater. all-Russian. (national). scientific-practical. conf. Kurgan, 245-248 (2020)

8. O.E. Likhodeevskaya, O.V. Gorelik, O.G. Loretts, Characteristics of the breeding stock of the pedigree reproducer of the Sverdlovsk region, Priority directions of regional development: collection of articles. mater. all-Russian. (national). scientific-practical. conf. with int. participation, Ekaterinburg, 716-720 (2020)

9. I.A. Shkuratova [et al.], Veterinary medicine and feeding, 2, $54-57$ (2020) (doi: 10.30917 / ATT-VK-1814-9588-2020-2-13)

10. L.I. Drozdova, V.L. Kosintsev, Condition of black-and-white holoshtinized cows and its relationship with metabolic diseases and morphofunctional changes in the liver, Innovative solutions of urgent problems in the agro-industrial complex: collection of articles. all-Russian. Scientific and practical conf. young scientists and specialists, Yekaterinburg, 107-111 (2013)

11. M.A. Chasovshchikova, Improvement of breeding and productive qualities of blackand-white cattle of the Northern Trans-Urals, 34 (Krasnoyarsk, 2016)

12. S.A. Chulichkova, The relationship of the morpho-biochemical composition of blood and the level of sex hormones in cows of the Holsteinized black-and-white breed in early pregnancy, 26 (Kazan, 2017)

13. A. Teneva, K. Hristov, G. Stoimenov, Bulgarian journal of agricultural science, 4 (26), 890-893 (2020)

14. O.M. Chernenko, M.O. Lieshchova, O.S. Orishchuk, O.I. Chernenko, O.I. Zaiarko, S.V. Tsap, O.G. Bordunova, V.R. Dutka, Bulgarian journal of agricultural science, 6(26), 1297-1304 (2020)

15. M.G. Polukhina Improving the selection of black-and-white and Simmental cattle in the Oryol region, 24 (Orel, 2015)

16. A.S. Batargaliev, Realization of the genetic potential of productivity of Holsteinized black-and-white cattle of the Volga region, 22 (Saratov, 2016)

17. O.N. Tselischeva, Factors of increasing milk productivity and milk quality of blackand-white cows, 20 (Saransk, 2016)

18. A.V. Klipova, The influence of the genotype of Holstein bulls of various breeding on the genetic progress of black-and-white cattle, 24 (Ulyanovsk, 2017)

19. Z.N. Privalova, Repeatability of signs of milk productivity in black-and-white cows with different productive longevity, 21 (Moscow, 2017)

20. T. Penev, I. Marinov, Zh. Gergovska, J. Mitev, Tch. Miteva, D. Dimov, R. Binev // Bulgarian journal of agricultural science, 3(23), 467-475 (2017)

21. I.A. Katsko, A.M. Lyakhovetskiy, K.N. Gorpinchenko, Yu.N. Zakharova, E.V. Kremyanskaya, A.E. Zhminko, Statistical methods of data processing: workshop, 89 (Krasnodar, KubGAU, 2017)

22. T.I. Berezina The use of black-and-white cows of different body types and Holstein blood for efficient milk production, 18 (Kinel, 2016) 
23. T.A. Guseva, Adaptive qualities of black-and-white cattle of various ecogenesis in the forest-steppe zone of the Middle Volga region, 22 (Penza, 2016)

24. O.G. Loretts [et al.], Agrarian Bulletin of the Urals, 12(154), 45-51 (2016)

25. O.S. Chechenikhina, O.G. Loretts, Agrarian Bulletin of the Urals, 7(186), 82-87 (2019) DOI 10.32417/article_5d52b0c25aab17. 78685760. 